\title{
Economic studies on unorganized dairy farms in Jaipur region of Rajasthan
}

\author{
J.K. Sharma* and N.K. Singh \\ School of Agriculture, Suresh Gyan Vihar University, Jaipur, Rajasthan, 302017 (India) \\ *Corresponding author: jks2508@ rediffmail.com
}

Journal of Livestock Science (ISSN online 2277-6214) 11: 127-132

Received on 20/5/2020; Accepted on 28/7/2020

doi. 10.33259/JLivestSci.2020.127-132

\begin{abstract}
The present study was undertaken to estimate the cost and return of milk production of un-organized dairy farms in Jaipur region of Rajasthan using dairy owner's level data from 50 unorganized dairy farms of 5 districts namely, Alwar, Dausa, Jaipur, Jhunjhnu and Sikar. The study was based on primary data collected through structured interview schedule. Production performance of each milch animal was calculated by taking the average cost and milk yield (liter/day/animal). The study revealed that among all the cost components, total feed and labour cost were the major ones. Feed cost varied from 54.22 to 57.07 percent in local cows to 57.07 percent in buffaloes and labour cost varied from 33.87 percent to 34.45 percent. Contribution of total variable cost varied from 90.56 to 94.08 percent. The average total maintenance cost for indigenous cows per liter in unorganized dairy farms worked out to be Rs.174.07 /animal/day. It was quite higher for a crossbred/exotic cows Rs.364.18/animal/day followed by buffalo Rs.345.86/animal/day. Despite the higher milk production cost, the cost of milk production of crossbreed/exotic cow was Rs.24.71/liter/day less than the indigenous cow and buffalo due to their better milk yield. Therefore, the cost per liter of milk produced by cross breed/exotic cow was comparatively low. The maintenance cost was observed lowest in rainy season in all milch animals due to availability of green fodder in sufficient amount. The analysis indicates that all breed of milch animals maintained by dairy owners in Jaipur region were profitable by minimum average net return per animal/per day which was recorded Rs.56.18 from local cows to maximum Rs. 175.64 in case of cross breed/exotic cows, whereas buffaloes contribute Rs.106.59. Similarly, the Benefit-Cost (B-C) ratio was also found maximum (1.44) in cross breed/exotic cows and minimum 1.25 for indigenous cows. Thus, the study revealed that cross breed/exotic cows were superior to indigenous cows and buffaloes in the study area.
\end{abstract}

Keywords: Fixed Cost; Variable cost; Jaipur region; Milk production; B-C ratio. 


\section{Introduction}

Dairying is an important subsidiary enterprise in rural and closely attached urban area of Rajasthan in terms of income and expenditure, thereby looking to this, the present study was purposely conducted in one of the most eminent milk producing region of Rajasthan and all five districts of Jaipur region namely, Alwar, Dausa, Jaipur, Jhunjhunu and Sikar were selected for collecting the desirable information. The average milk production of Rajasthan state as a whole is 12,972 million tons and the contribution of the milk production of Jaipur is 3,513 million tons which is about 27.47 percent of the district comprised in the study area was $1014,384,1008,478$,and 629 million tons in Alwar, Dausa, Jaipur, Jhunjhnu and Sikar respectively (Source: Integrated Sample Survey Reports (2001-02 to 2013-14), Department of Animal Husbandry, Govt. of Rajasthan. By NDDB Dairying in Rajasthan - A Statistical Profile 2016 Part IV: Milk Production page no.67)

The cost and return in dairy enterprise are important aspects for milk producers, consumers and policy makers and planning organizations such as government and animal husbandry departments to provide an effective input for making rational economic decisions. In spite of number of studies attempted by various researcher of the country in respect of dairying It was felt that further studies are to be conducted in Jaipur region due to varied agroclimatic condition of the area, resource availability and technological knowledge about dairy farming (Nagrale et al 2007, Bhowmik \& Sirohi 2008, Bardhan \& Sharma 2012, Sharma 2013, Chand et al 2017, Singh et al 2012, Beyero et al 2015, Lal and Chandel 2016, Patel et al, 2016, Jadav et al 2016, Deshetti et al 2017, Prem Chand et al 2018, and Joshi et al 2018).

\section{Material and methods}

The present study was conducted in Jaipur region Rajasthan as it is one of the major milk producing and progressive region in the dairy development activities. All the five districts comprise in Jaipur region namely, Alwar, Dausa, Jaipur, Jhunjhnu and Sikar were selected purposely. Further five tehsils from each district were selected randomly and two un-organized dairy farms were selected from each tehsil simultaneously and randomly. The selected tehsils were Malakhera, KishanGarh bas, Govindgarh, Rajgarh and Reini from Alwar district, Baswa, Ramgarhpachwara, Lawan, Sikarai and Nagal from Dausa district, Amer, Bassi, Chomu, Chaksu and Jamwaramgarh from Jaipur district; Jhunjhunu, Chirawa, Navalgarh, Udaipur wati and Buhana from Jhujhnu district and Sikar, Fatehpur, Laxman Garh, Dhod and Srimadhopur from Sikar district. Therefore, 10 un-organized dairy farms were selected from each district within 30 kilometer radius from district headquarter, thereby total 50 dairy farms were selected from the entire region for the study. Both primary and secondary data were used for the study. The primary data was collected from 50 selected dairy farms for the year 2017-2018. Standard methodology was used to estimate the cost of milk production and return from various species of dairy animals to identify the major detriments influencing the economics of dairy business in Jaipur region of Rajasthan. The methodology for estimation of cost and return in dairying is quiet older particularly the computation of capital cost, variable cost etc. Due to the improved breeding practices, changing management practices and labour used pattern, the new concept for calculation of the cost and return in milk production was refined by some researcher (Sirohi et.al 2015). Therefore, the refined concept was incorporated in the present study. The milch bovines maintained by selected dairy owners were indigenous cow breeds namely Sahiwal, Rathi, Gir, Mewati and Tharparkar, Cross breed cows (The crosses from exotic breeds like Jersey and Holestien friesien with Rathi, Sahiwal, Mewati and Tharparkar were found and exotic breeds Jersey and Holstein Friesiens were maintained by dairy owners. Similarly Murrah, Surti and Jafarabadi buffaloes were kept in dairy farms.

Net profit was measured by subtracting the total expenditure on rearing of dairy animals from the total return. The value of each component was added together to determine the total fixed and variable cost for each animal. The relevant components of fixed cost included in milk production were interest and depreciation on fixed capital. The value of animal and cattle shed and other fixed items used in rearing the milch animals and milk production was taken to work out interest on fixed capital. The interest on working capital was not taken into consideration as the house hold gets income from milk every day. The interest rate on cattle and cattle shed was worked out to be @ $12.5 \%$ per annum considering the prevailing interest rate of various financial institutions. The depreciation on milch indigenous cow as was charged @ 8.34\% assuming 12 years as a productive life cycle. Variable costs included those recurring components in milk production, which are incurred on feed and fodder, labour expenses, expenditure on breeding and healthcare management and miscellaneous expenses like electricity etc. The total cost was worked out by adding together total fixed cost and total variable cost .The net cost arrived after deducting, the value of the dung from total cost and net income was obtained after deducting the net cost from the value of milk production. The gross return on per animal per day was obtained by adding the value of milk produced and the dung value by multiplying it by the price of milk per liter and price of dung per $\mathrm{kg}$. 


\section{Result and discussion}

Herd-Size

Study reveals that the average herd size under the study of 50 dairy farms having 45.99 animals maintained by a dairy farm (Table 1). Out of these, about 13.73(29.85\%) were indigenous cows, $26.16(56.88 \%)$ cross breed/exotic breed cows and $6.1(13.73 \%)$ buffaloes were kept by a dairy farm. The total adult milch animals of indigenous cows 8.04(58.56\%), 26.26(77.45\%) of cross breed/exotic cows and 4.36(71.48\%) buffaloes were recorded in the study area. Thus, Table -1 clearly indicated that all dairy owners preferred to maintain a large number ( $57 \%$ cross breed/Exotic breed cows) of the total animal maintained by them on their farm.

\section{Feeding pattern}

The qualitative and quantitative feeds supplied to the milch animals play an important role in maintaining the animals' health and level of milk production. The feed and fodder supplied by dairy owners to their animals is indicated in (Table 2). It has been observed that on an average dry fodder per animal was estimated as $5.3 \mathrm{~kg}, 12.5 \mathrm{~kg}$ and $11.02 \mathrm{~kg} /$ animal/day for indigenous cows, exotic/cross breed and buffaloes respectively. However in case of green fodder, dairy owners provided $4.79 \mathrm{Kg}, 9.78 \mathrm{Kg}$ and $9.83 \mathrm{Kg} /$ animal/day for indigenous, exotic/cross breed cows and buffaloes respectively. The major feeding practice adopted by dairy owners for feeding their domestic animals was stalled feeding rather than grazing in the study area.

Wheat straw was used as dry fodder; however Lucerne and Berseem were supplied as green fodder in general. Concentrate mix that was fed to the pregnant and milch animals comprised of cotton seed cake (CSC), mustard seed cake (MSC), ground nut seed cake (GNC) and broken grains of rice, wheat and bajra.

\section{Cost of milk production and income from dairying}

The cost of milk production was classified as fixed and variable cost on the basis of fixed and variable cost components. Cost and return from milk production are directly related to the net income of dairy owner. Higher cost leads to low net income. It has been observed (Table 3) that average productivity of milch indigenous cows was 6.05liter/day/animal. Milk production of cross breed/ exotic cows was quite higher 15.29liter/day/animal against indigenous cows and buffaloes (7.84liter). The average gross maintenance cost for indigenous cow was worked out to be Rs.161.93/animal/day. The gross maintenance cost for cross breed/exotic cows and buffaloes were quite higher than the indigenous cows and it was Rs. 364.18 for cross/exotic cows and Rs. 345.86 for buffaloes respectively. In gross maintenance cost, more than $90 \%$ share was for variable cost. Feed and fodder cost accounted higher (54 to $57 \%$ ) of total cost followed by labour cost (34 to 36\%) in all types of milch animals. The net maintenance cost was estimated minimum in indigenous cows (Rs 161.93/animal/day) against buffaloes (Rs. 330.99/animal/day). The maintenance cost was lower in rainy season than in winter and summer. The per liter average cost of milk production was estimated Rs. 29.13 for indigenous cows, Rs. 24.71 for cross breed/exotic cow and it was quite higher Rs. 45.60 for buffaloes. It was due to low milk production. Despite of higher maintenance cost, the cost of milk production of cross breed/exotic cows was quite lower (Rs. 24.71 /liter) than the indigenous cows and buffaloes due to the better production performance. The net profit margin from per liter of milk production for indigenous cows was Rs.8.89 and Rs. 6.65 for buffaloes and it was higher for cross/exotic cattle (Rs.10.73). Thus, it can be revealed that the crossbreed/exotic cows were very profitable in the region as in case of other part of the country reported by several authors (Nagrale et al 2007, Gauraha 2007, Jaiswal and Singh 2015, Sinha et al 2012, Malsawmdawngliana \& Rahman, 2016, Chand et al 2017 and Joshi et al 2018).

\section{Conclusion}

Based on the results from the study of 50 un-organized dairy farms of Jaipur region of Rajasthan, it is concluded that rearing of buffaloes was not commonly preferred by dairy owners as they faced difficulties in relation to various management practices in the study area. Similarly in respect of indigenous cow was also not much popular due to the commercial point of view because of the higher maintenance cost and lower productivity. However, crossbreed/exotic cow was economically viable due to higher productivity in spite of higher maintenance cost and largely preferred by dairy owners in the study area.

\section{Acknowledgement}

The author wishes to acknowledge the Head of School of Agriculture, Suresh Gyan Vihar University, Jaipur for providing necessary facilities during his present investigation. 
Table 1 Average herd size in selected dairy farms in Jaipur region of Rajasthan

\begin{tabular}{|c|c|c|c|c|c|c|c|c|}
\hline \multirow[t]{2}{*}{ Particular } & \multicolumn{2}{|c|}{ Indigenous cows } & \multicolumn{2}{|c|}{$\begin{array}{c}\text { Exotic /Cross breed } \\
\text { cows }\end{array}$} & \multicolumn{2}{|c|}{ Buffaloes } & \multicolumn{2}{|c|}{ Average } \\
\hline & Number & $\%$ & Number & $\%$ & Number & $\%$ & Number & $\%$ \\
\hline In Milk (Pregnant) & 4.84 & 60.20 & 10.74 & 53.01 & 2.22 & 50.92 & 17.8 & 54.50 \\
\hline Total (Milch Ind.Cow) & 6.68 & 83.08 & 16.14 & 79.66 & 3.54 & 81.19 & 26.36 & 80.71 \\
\hline Dry Pregnant & 0.9 & 11.19 & 2.32 & 11.45 & 0.62 & 14.22 & 3.84 & 11.76 \\
\hline Dry not Pregnant & 0.46 & 5.72 & 1.8 & 8.88 & 0.2 & 4.59 & 2.46 & 7.53 \\
\hline Total Adult Female & 8.04 & $100 \%$ & 20.26 & $100 \%$ & 4.36 & $100 \%$ & 32.66 & $100 \%$ \\
\hline \multicolumn{9}{|l|}{ Heifers above 2Year } \\
\hline Pregnant Heifer & 1.16 & 1.98 & 1.9 & 2.45 & 0.8 & 1.12 & 3.86 & 5.44 \\
\hline Not Pregnant Heifer & 1.52 & 2.60 & 2.42 & 3.12 & 0.56 & 0.78 & 4.5 & 6.34 \\
\hline Total Young Stock below 2 year & 3.52 & 6.01 & 5.9 & 7.62 & 1.74 & 2.43 & 11.16 & 15.71 \\
\hline \multirow[t]{2}{*}{ Draught animal } & 2.17 & 3.71 & & 0.00 & & 0.00 & 2.17 & 3.06 \\
\hline & 13.73 & 58.56 & 26.16 & 77.45 & 6.10 & 71.48 & 45.99 & 71.02 \\
\hline
\end{tabular}

Table 2. Feeding pattern of milch animals in Jaipur region of Rajasthan (per animal/per day)

\begin{tabular}{|c|c|c|c|c|c|c|c|c|c|c|c|}
\hline \multirow[t]{2}{*}{ Particular } & \multicolumn{4}{|c|}{ Indigenous Cows } & \multicolumn{4}{|c|}{ Cross breed/Exotic Cows } & \multicolumn{3}{|c|}{ Buffaloes } \\
\hline & Summer & Rainy & Winter & Overall & Summer & Rainy & Winter & Overall & Summer & Rainy & Winter \\
\hline Dry Fodder(Kg) & 6.54 & 3.6 & 5.8 & 5.31 & 11.78 & 11.96 & 13.02 & 12.25 & 11.96 & 8.8 & 12.3 \\
\hline Green Fodder $(\mathrm{Kg})$ & 3.46 & 6.54 & 4.36 & 4.79 & 6.27 & 11.6 & 11.48 & 9.78 & 5.84 & 11.26 & 12.38 \\
\hline Concentrates $(\mathrm{Kg})$ & 2.87 & 2.87 & 2.87 & 2.87 & 5.37 & 5.37 & 5.37 & 5.37 & 5.59 & 5.59 & 5.59 \\
\hline Mineral Mixture $(\mathrm{Gm})$ & 52.3 & 52.3 & 52.3 & 52.2 & 114.5 & 114.5 & 114.5 & 114.5 & 93.6 & 93.6 & 93.6 \\
\hline Liq.Supplements(Ml) & 63 & 64 & 65 & 63 & 119 & 119 & 119 & 119 & 128 & 128 & 128 \\
\hline
\end{tabular}


Table 3 Maintenance cost of dairy animals in Jaipur region (in Rs.) /day /animal

\begin{tabular}{|c|c|c|c|c|c|c|c|c|c|c|c|c|c|c|c|}
\hline \multirow[t]{2}{*}{ Components } & \multicolumn{5}{|c|}{ Indigenous cow } & \multicolumn{5}{|c|}{ Cross Breed/Exotic cow } & \multicolumn{5}{|c|}{ Buffaloes } \\
\hline & Summer & Rainy & Winter & Average & $\%$ & Summer & Rainy & Winter & Average & $\%$ & Summer & Rainy & Winter & Average & $\%$ \\
\hline \multicolumn{16}{|l|}{ A-Fixed Cost } \\
\hline Interest on fixed capital & 14.1 & 14.1 & 14.1 & 14.1 & 8.1 & 18.2 & 18.2 & 18.2 & 18.2 & 5 & 22.2 & 22.2 & 22.2 & 22.2 & 6.42 \\
\hline Depreciation & 2.34 & 2.34 & 2.34 & 2.34 & 1.34 & 3.34 & 3.34 & 3.34 & 3.34 & 0.92 & 3.55 & 3.55 & 3.55 & 3.55 & 1.03 \\
\hline Total Fixed Cost & 16.44 & 16.44 & 16.44 & 16.44 & 9.44 & 21.54 & 21.54 & 21.54 & 21.54 & 5.91 & 25.75 & 25.75 & 25.75 & 25.75 & 7.45 \\
\hline \multicolumn{16}{|l|}{ B-Vaiable Cost } \\
\hline Dry Fodder & 13.08 & 10.8 & 14.5 & 12.793 & 7.35 & 29.4 & 32.58 & 32.55 & 31.51 & 8.65 & 23.92 & 26.64 & 30.75 & 27.1 & 7.84 \\
\hline Green Fodder & 17.3 & 16.35 & 26.16 & 19.937 & 11.45 & 53.3 & 48.1 & 72.4 & 57.933 & 15.9 & 50.7 & 33.05 & 65 & 49.58 & 14.34 \\
\hline Concentrate & 54.53 & 54.53 & 54.53 & 54.53 & 31.33 & 102.03 & 102.03 & 102.03 & 102.03 & 28 & 106.21 & 106.2 & 106.2 & 106.2 & 30.71 \\
\hline Mineral Mix & 3.5 & 3.5 & 3.5 & 3.5 & 2.01 & 7.5 & 7.5 & 7.5 & 7.5 & 2.06 & 7.5 & 7.5 & 7.5 & 7.5 & 2.17 \\
\hline Liq.Feed Suppl. & 4.5 & 4.5 & 4.5 & 4.5 & 2.59 & 8.5 & 8.5 & 8.5 & 8.5 & 2.33 & 7 & 7 & 7 & 7 & 2.02 \\
\hline Total Feed Cost & 92.91 & 89.68 & 103.19 & 95.26 & 54.72 & 200.73 & 198.71 & 222.98 & 207.47 & 57 & 195.33 & 180.4 & 216.46 & 197.4 & 57.07 \\
\hline Hired Labour & 58.6 & 55.6 & 62.66 & 58.953 & 33.87 & 133.2 & 125.6 & 131.24 & 130.01 & 35.7 & 124.34 & 112.45 & 116.45 & 117.7 & 34.04 \\
\hline Micella neous & 1.31 & 1.31 & 1.31 & 1.31 & 0.75 & 1.8 & 2.1 & 2.15 & 2.0167 & 0.55 & 1.8 & 2.1 & 2.15 & 2.017 & 0.58 \\
\hline $\begin{array}{l}\text { Veterinary,A.I. ,Ins. and } \\
\text { other exp. }\end{array}$ & 2.11 & 2.11 & 2.11 & 2.11 & 1.21 & 3.10 & 3.25 & 3.05 & 3.13 & 0.86 & 2.55 & 3.25 & 3.05 & 2.95 & 0.85 \\
\hline Total Variable Cost & 154.93 & 148.7 & 169.27 & 157.63 & 90.56 & 338.83 & 329.66 & 359.42 & 342.64 & 94.1 & 324.02 & 298.2 & 338.11 & 320.11 & 92.55 \\
\hline Total Cost $(\mathrm{A}+\mathrm{B})$ & 171.37 & 165.14 & 185.71 & 174.07 & 100 & 360.37 & 351.2 & 380.96 & 364.18 & 100 & 349.77 & 323.95 & 363.86 & 345.86 & 100 \\
\hline Value of Dung & 11.52 & 13.12 & 11.78 & 12.14 & & 14.52 & 16.76 & 18.22 & 16.5 & & 16.1 & 13.42 & 15.1 & 14.87 & \\
\hline Net Cost & 159.85 & 152.02 & 173.93 & 161.93 & & 345.85 & 334.44 & 362.74 & 347.68 & & 333.67 & 310.53 & 348.76 & 330.99 & \\
\hline Milk Yield/lter./day & 5.16 & 6.75 & 6.25 & 6.05 & & 11.47 & 17.92 & 16.49 & 15.29 & & 6.28 & 9.57 & 7.66 & 7.84 & \\
\hline Value of Milk Production & 180.6 & 236.3 & 237.5 & 218.12 & & 401.45 & 591.4 & 577.2 & 523.32 & & 351.68 & 516.8 & 444.3 & 437.58 & \\
\hline Net Income/Day & 20.75 & 84.23 & 63.57 & 56.18 & & 55.6 & 256.92 & 214.41 & 175.64 & & \begin{tabular}{|l|}
18.01 \\
\end{tabular} & 206.25 & 95.52 & 106.59 & \\
\hline Cost per Liter & 33.21 & 24.47 & 29.71 & 29.13 & & 31.42 & 19.6 & 23.1 & 24.71 & & 55.7 & 33.85 & 47.5 & 45.68 & \\
\hline Net Income /ltr & 4.02 & 12.48 & 10.17 & 8.89 & & 4.85 & 14.34 & 13 & 10.73 & & -0.7 & 16.15 & 4.5 & 6.65 & \\
\hline B-C Ratio & 1.05 & 1.43 & 1.28 & 1.25 & & 1.11 & 1.68 & 1.51 & 1.44 & & 1.01 & 1.60 & 1.22 & 1.27 & \\
\hline
\end{tabular}




\section{References}

1) Bardhan, D., Sharma, M.L. 2012. Economics of milk production in Kumaun region of Uttarakhand. Indian Journal of Dairy Science. 65(5): 416-22.

2) Beyero, N., Kapoor, V., Tewatia, B.S. 2015. Effect of rough age to concentrate ratio in the diet on milk production and fatty acid profile of milk in crossbred cows. Indian Journal of Dairy Science. 32(4): 373-78.

3) Bhowmik, P., Sirohi, S. 2008. Cost of milk production and returns from dairying in South Tripura. Indian Journal of Dairy Science. 61(4): 303-07.

4) Chand, P., Sirohi, S., Mishra, A., Chahal, V.P. 2017. Estimation of costs and returns from dairying .in Malwa region of Madhya Pradesh. Indian Journal of Dairy Science. 87(3): 381-86.CSO. 2017.

5) Deshetti, M.B., Teggi, M.Y., Hosamani, S.V. 2017. Milk production and resource use efficiency of dairy farming under stall-fed condition in Karnataka. Indian Journal of Dairy Science. 70(4): 466-70.

6) Gauraha, A. K. 2007. Economics of milk marketing in Chhattisgarh. Indian Journal of Agriculture Economics. 62(3):463-64.

7) Jadav, S.J., Durgga, R.V., Tyagi, K.K., Singh, R.R. 2016. Economic performance of rural and periurban dairy farmers. Journal of Livestock Science 7: 215-219.

8) Jaiswal, P., Singh, R.K. 2015. Economics of milk production and determinants of market participation for small holder dairy farmers in Raipur district of Chhattisgarh. Indian Journal of Dairy Science 68(6): 619-28.

9) Joshi, P., Tiwari, R., Dutt, T., Singh, P.K. 2018. Economics of Badri cattle rearing in Uttrakhand, Indian Journal of Animal Sciences 88(8):977-978.

10) Malsawmdawngliana, R. and Rahman, S. 2016. Management practices followed by the dairy farmers of Mizoram, India. Journal of Livestock Science 7: 220-225.

11) Nagrale, B.G., Datta, K.K., Singh, S.R. 2007. Cost of milk production in Vidarbha region of Maharashtra. Indian Journal of Dairy Science. 64(6): 514-19.

12) Patel, J.H., Prajapati, K.B., Sheikh, A.S., Patel, M.D., Chaudhari, S.S. 2016. Traditional feeding practices adopted by professional breeders of Kankrej cattle in Banaskantha district of Gujarat state. Journal of Livestock Science 7: 49-53

13) Prem Chand, Sirohi S., Saxena R. and Mishra A. 2018. How profitable is dairying in tribal Chattisgarh? Indian Journal of Animal Sciences 88(6):749-754.

14) Lal, P., Chandel, B.S. 2016.Economics of milk production and cost elasticity analysis in Sirsa district of Haryana Economic Affairs Citation: EA: 61(3): 405-411.

15) Sharma, A. 2013. 'Economic viability of commercial dairy farms in Jabalpur district of Madhya Pradesh.'M.Sc Dissertation, National Dairy Research Institute, Karnal.

16) Sinha, M.K., Dhaka, J.P., Meena, M.S. 2012. Milk production economics and micro financing impacts in Chhotanagpur plateau of Jharkhand. Indian Journal of Animal Sciences .82(7):757-61.

17) Sirohi, S., Saxena, R., Chauhan, A.K., Dhaka, J.P., Sirohi, S.K., Kumar, N, Sharma, D., Pal, K., Agrawal, P., Sharma, A., Kumar, S., Feroze, S.M., Burdhan, D., Kumar, S., Chand, P. Fulpagare, Y.G 2015. Costs and returns in milk production: Developing standardized methodology and estimates for various production systems. Project report Submitted to Department of Animal Husbandary, Dairying and Fisheries, Ministry of Agriculture, Govt. of India, New Delhi. 